\title{
A new species of Austrolebias Costa (Cyprinodontiformes: Rivulidae) from northeastern Uruguay, with comments on distribution patterns
}

\author{
Marcelo Loureiro ${ }^{1,2}$, Alejandro Duarte ${ }^{1}$ and Matías Zarucki ${ }^{1}$
}

A new species of Austrolebias is described based on individuals from the middle and upper río Negro (río Uruguay basin) and río Yaguarón (Patos-Merín system). The new species can be differentiated from all other species of the genus by the unique presence in males of uniform bluish gray pigmentation on flanks (without vertical bands) and unpaired fins. The new species is also distinguished by the combination of characters associated with a reduction of the squamation of the abdominal, preopercular, and opercular regions. The new species presents some morphological characteristics similar to A. gymnoventris and A. luteoflammulatus. The distribution of the new species is concordant with three other species of Austrolebias and may represent a case of drainage rearrangement of the río Negro upstream tributaries (río Uruguay basin) and tributaries of laguna Merín system.

Uma espécie nova de Austrolebias é descrita, com base em indivíduos do alto e médio rio Negro (bacia do rio Uruguai) e rio Jaguarão (sistema Patos-Mirim). A espécie nova pode ser distinguida de todas as demais do gênero pela presença única em machos de pigmentação uniforme cinza azulado nos flancos sem listras verticais, e a pigmentação uniforme das nadadeiras ímpares. Também pode ser reconhecida pela combinação de caracteres associados à redução do padrão de escamas na região abdominal, pré-opérculo e opérculo. A espécie nova apresenta várias características semelhantes a $A$. gymnoventris e a $A$. luteoflammulatus. A distribução da espécie nova é concordante com outras três espécies de Austrolebias, representando um caso potencial de captura da bacia dos afluentes superiores do rio Negro (bacia do rio Uruguai) aos afluentes da lagoa Mirim.

Key words: Annual fishes, Biogeography, Systematics.

\section{Introduction}

Species of the genus Austrolebias Costa are the most numerous annual fishes of temporary ponds and wetlands in the lower Plata-Paraná basin and the Patos-Merín system. There are 39 currently recognized species (Costa, 2006; Ferrer et al., 2008; Loureiro \& García, 2008), most (65\%) described in the last 25 years.

Monophyly of the genus is supported by molecular (García et al., 2000; García, 2006) and morphological analysis (Costa, 2006). According to Costa (2006), synapomorphies that support Austrolebias monophyly comprise head scale patterns, pigmentation around the eyes, bony structures of the lower jaw and the gill arches, morphology of the unpaired fins, and genital morphology. Phylogenetic relationships within the genus are considered controversial because morphological and molecular analyses are contradictory
(Costa, 1998, 2002, 2006; García et al., 2000; García, 2006; Loureiro, 2004). According to the most recent revision (Costa, 2006), the genus includes three basal species and five species groups. Despite the fact that these groups were roughly supported by molecular analyses (García et al., 2000; García, 2006), phylogenetic relationships among and within clades are still the subject of debate.

Due to their peculiar life cycle and habitat, which favors high local differentiation and low vagility, annual fishes are an excellent model group to test speciation mechanisms and historical biogeographic hypotheses. Yet, absence of a robust phylogenetic hypothesis for the group, make interpretations weak. However, some general patterns are still evident. At a large geographical scale Costa (2010) suggested that the ancestor of Austrolebias probably originated in the lower La Plata basin (including the río Negro) and the Patos-Merín system, and later different dispersal and vicariant events

${ }^{1}$ Sección Zoología Vertebrados, Departamento de Ecología y Evolución, Facultad de Ciencias, Universidad de la República. Iguá 4225, CP 11400 Montevideo, Uruguay. mapy@fcien.edu.uy

${ }^{2}$ Departamento de Ictiología, Museo Nacional de Historia Natural, Montevideo, Uruguay. 
shaped the current distribution patterns. Despite some exceptions (García et al., 2000; Loureiro, 2004; Costa, 2006) distribution of the species of Austrolebias are restricted to small areas, e.g. the critically endangered species $A$. cinereus (Amato) (Loureiro et al., 2007) which is known from a single pond in the lower río Uruguay basin (Amato, 1986; Costa, 2006). Distribution patterns are strongly associated with river basins or drainage areas and, in general, sister species occupy allopatric adjacent areas. One exception is the parapatric sister species A. charrua Costa \& Cheffe and A. reicherti (Loureiro \& García) (Loureiro \& García, 2004, 2008; García et al., 2009). Another such case was reported by Loureiro et al. (2004) for A. arachan Loureiro, Azpelicueta \& García and A. vazferreirai (Berkekamp, Etzel, Reichert \& Salvia), which occupy upstream regions of the río Negro drainage (río Uruguay basin) and an upstream region of the río Tacuarí drainage (Patos-Merín system).

Here, we describe a new species of the genus Austrolebias from the upper río Negro and río Yaguarón basins that we postulate to be related to the basal A. gymnoventris (Amato) and A. luteoflammulatus (Vaz-Ferreira, Sierra \& Scaglia). We also compare the distribution of the new species with those of the sympatric A. arachan, and A. vazferreirai, and other Austrolebias species from the region.

\section{Material and Methods}

Specimens analyzed and comparative material are deposited in the Fish Collection of Facultad de Ciencias, Universidad de la República, Montevideo (ZVC-P); distributional data of Austrolebias arachan, A. melanoorus, A. vazferreirai (Amato), and the $A$. affinis species group were obtained from ZVC-P catalogue database, Costa (2006), and Volcan et al. (2010). Morphometric and meristics counts were recorded under dissecting microscope following Costa (1989) and Loureiro \& García (2008). Cephalic neuromast series nomenclature follows Costa (2001). Cleared and counterstained specimens (c\&s) were prepared following Dingerkus \& Uhler (1977). Species groups names and composition follow Costa (2006).

\section{Austrolebias quirogai, new species Fig. 1}

Holotype. ZCV-P 9758, male, 36.8 mm SL, Uruguay, Departamento de Cerro Largo, río Negro basin, pond near arroyo Cordobés, 32³6'59' S 55¹9'24'W, Sep 2009, M. Loureiro, M. Zarucki \& A. Duarte.

Paratypes. Uruguay, Departamento de Cerro Largo. ZVC-P 8725, 33 males, 24.7-38.2 mm SL (5 c\&s), 36 females, 21.0-29.9 $\mathrm{mm}$ SL (5 c\&s), río Negro basin, pond near arroyo Cordobés, 32³6'59' S 5519'24'W, Sep 2009, M. Loureiro, M. Zarucki \& A. Duarte. ZVC-P 8742, 25 males, 23.3-34.0 mm SL (2 c\&s), 20 females, 20.1-26.0 mm SL, río Negro basin, pond near arroyo Quebracho, 32³5'29'S 5441'6.44'W, Sep 2009, M. Loureiro, M. Zarucki \& A. Duarte. ZVC-P 8699, 10 males, 37.3-48.2 mm SL (2 c\&s), 28 females, 29.4-36.4 mm SL (6 c\&s), río Negro basin,

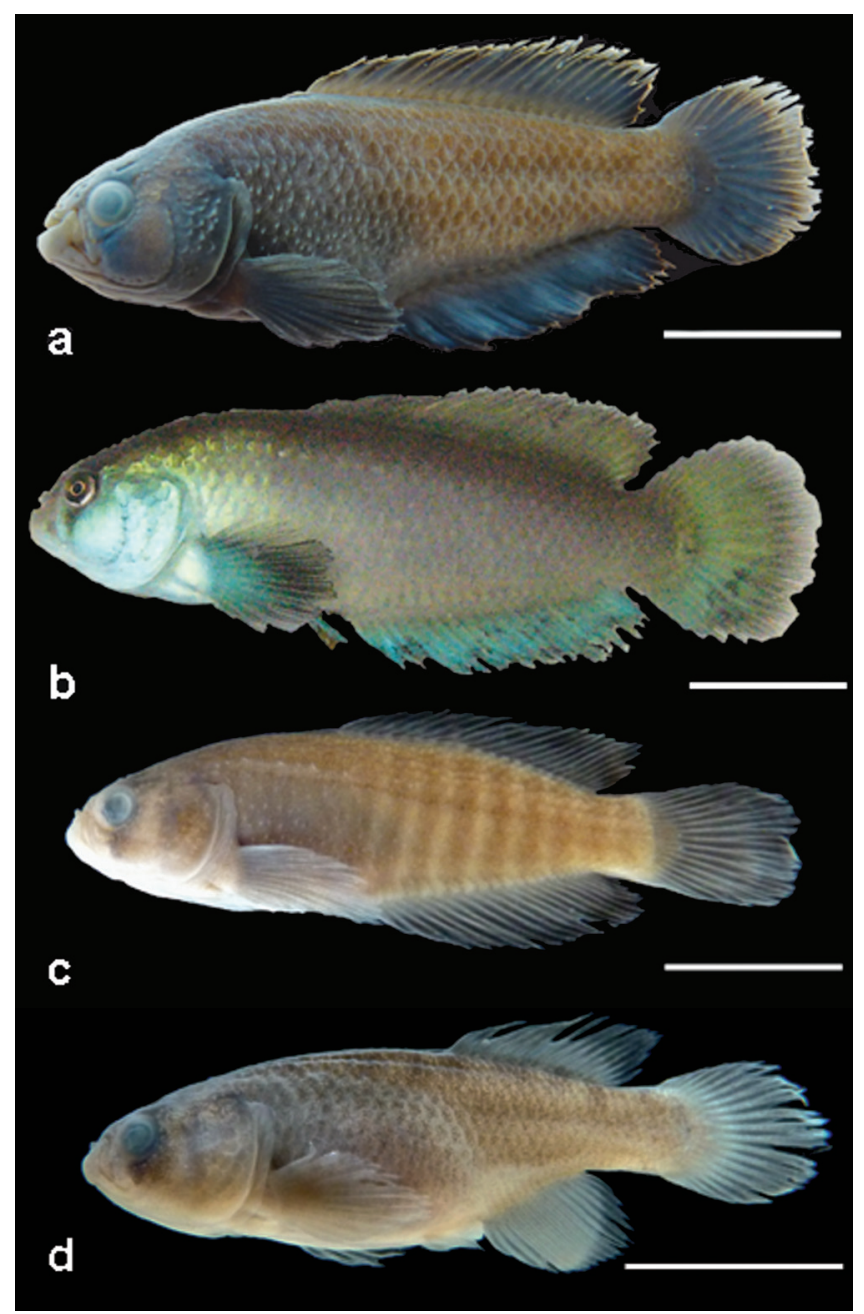

Fig. 1. a. Holotype of Austrolebias quirogai (ZVC-P 9758, 36.8 $\mathrm{mm} \mathrm{SL}$ ); b. Live male, paratype, from type locality (ZVC-P 8725 , $39.8 \mathrm{~mm} \mathrm{SL}$ ); c. male, paratype (ZVC-P 8742,31.2 mm SL) showing rare pigmentation pattern. $\mathbf{d}$. Female, paratype, from type locality (ZVC-P 8725, $27.8 \mathrm{~mm} \mathrm{SL}$ ). Scale bars $=10 \mathrm{~mm}$.

pond near arroyo Quebracho, 32³5'29'S 5441'6.44'W, Sep 2007, M. Loureiro, S. Clavijo-Baquet, M. Zarucki \& F. Teixeira de Mello. ZVC-P 7743, 2 females, 28.2-30.2 mm SL, río Negro basin, pond near río Negro at Paso Mazangano, route 44, 32 $06^{\circ} 37^{\prime \prime} \mathrm{S}$ 54³8'20"W, 23 Sep 2003, M. Loureiro. ZVC-P 7758, 3 females, 28.6-29.0 mm SL, Laguna Merín basin, pond near río Yaguarón at Paso San Diego, 31 58 '37' S 5355'20'W, Sep 2007, M. Loureiro, S. Clavijo-Baquet, M. Zarucki \& F. Teixeira de Mello. ZVC-P 8731, 36 males, 24.7-30.6 mm SL (5 c\&s), 34 females, 16.0-22.7 mm SL ( 5 c\&s), Laguna Merín basin, pond near Río Yaguarón at Paso San Diego, 31 58 '37'S 5355'20'W, Sep 2009, M. Loureiro, M. Zarucki \& A. Duarte. Departamento de Rivera. ZVC-P 7807, 2 males, 31.4-31.5 mm SL, río Negro basin, pond near río Negro North of Paso Mazangano, route 44, 31 ${ }^{\circ} 59^{\prime} 14$ '”S 54³2'59'”W, 8 Aug 2004, M. Loureiro, F. Teixeira de Mello, A. D'Anatro \& E. Charbonier.

Diagnosis. The new species is distinguished from all other species of Austrolebias by the unique pigmentation pattern of body and fins in males. This consists of a uniform bluish 
gray background color on the body that lacks vertical bands, and uniform pigmentation of unpaired fins. Most individuals of the new species can also be recognized by the combination of characters associated with reduced squamation in the abdominal, preopercular, and opercular regions. Reduction in the number of scales in the abdomen occurs in three alternative states: a completely naked abdomen, only a ventral row of small scales, or just area below pectoral fin without scales ( $v S$. scales always absent in anterior part of the abdomen as in $A$. gymnoventris). The preopercular region is either completely naked or only has a few scales present in its center ( $v s$. preopercular region always naked as in A. gymnoventris). The opercular region is from completely naked to only distal edge naked (vs. only opercular distal edge naked as in $A$. gymnoventris). In extremely large males (SL $>40 \mathrm{~mm}$ ) and females (SL $>34 \mathrm{~mm}$ ), which represent less than $7 \%$ of individuals analyzed (Fig. 2), scales almost completely cover the preopercular, opercular, and abdominal regions.

Description. Morphometric data in Table 1. Body elongate, laterally compressed. Dorsal profile from dorsal tip of mouth to back of head straight, slightly convex to origin of dorsal
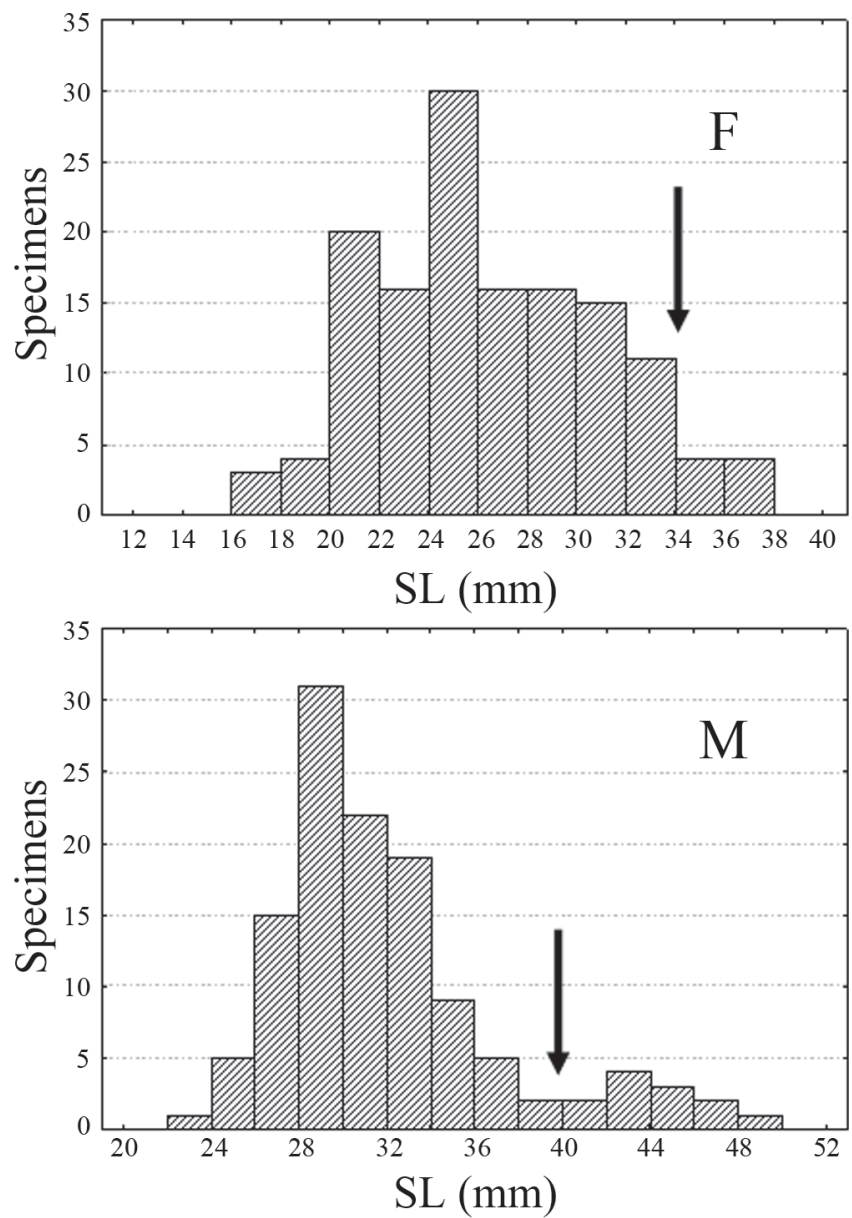

Fig. 2. Size distribution of individuals analyzed of Austrolebias quirogai. Arrows indicate size above which there is little or no reduction in squamation patterns; F. females, M. males. fin, straight below dorsal fin, and straight on caudal peduncle. Ventral profile arched from tip of lower jaw to origin of anal fin, straight over anal fin, and straight on caudal peduncle. Mouth slightly prognathous.

Dorsal-fin rays in males 19-27 (mode 23); in females 15-19 (mode 17). Dorsal and posterior tip of dorsal fin of males rounded. Origin of dorsal fin in males at vertical through vertebrae 6 and 8 in males, in females through vertebrae 10 and 12. Anal-fin rays in males 17-24 (mode 21); in females 1419 (mode 17). Anal-fin tip rounded in males. Anal-fin contour rounded in females. Anal-fin origin at vertical through $3^{\text {rd }}$ and $7^{\text {th }}$ (mode $\left.5^{\text {th }}\right)$ dorsal-fin rays in males and through $2^{\text {nd }}$ and $5^{\text {th }}$ (mode $4^{\text {th }}$ ) in females. Caudal fin distal margin rounded, 16-23 (mode 20) rays in males and 16-23 (mode 21) fin rays in females. Caudal-fin rays supported by last 4 or 5 (mode 4) vertebrae. Pectoral fin rays 9-14 (mode 11) in males, 10-12 (mode 11) in females; pectoral-fin margin rounded in males, slightly pointed in females. Pectoral-fin posterior tip reaching from urogenital papilla to $5^{\text {th }}$ anal-fin ray in males, from origin of pelvic fin to $3^{\text {rd }}$ anal-fin ray in females. Three pectoral-fin radials. Pelvicfin rays 4 or 5 (mode 5). Pelvic-fin posterior tip from origin of anal fin to $4^{\text {th }}$ anal-fin ray in males, from urogenital papilla to $3^{\text {rd }}$ fin ray in females. Pelvic fins separated from each other. Total number of vertebrae 28-31 (mode 30), 11-13 (mode 13) precaudal; 2-4 (mode 3 ) flattened anterior neural spines.

Scales cycloid, 27-34 (mode 29) in lateral series; transverse scales 11-19 (mode 14) in males, 10-18 (mode 16) in females; scales around caudal peduncle 10-21 (mode 17). Preopercular and opercular region of adults of less than $40 \mathrm{~mm}$ of SL (males) and less than $34 \mathrm{~mm}$ of SL (females) with naked areas lacking scales, from completely naked to edges without scales (Fig. 3a). Abdominal region same pattern of scale reduction: completely naked, only one ventral row of small scales, or area below pectoral fin without scales (Fig. 3d).

Contact organs on scales throughout most of body, more conspicuous on abdominal and opercular regions. Contact organs on inner surface of pectoral rays with bony support from first to sixth ray. Contact organs on $2^{\text {nd }}$ to $8^{\text {th }}$ anal-fin rays, in some males with bony support from $2^{\text {nd }}$ to $6^{\text {th }}$.

Cephalic neuromast series: Anterior rostral 2; posterior rostral 2; supraorbital 11-19; parietal 1-2; infraorbital 15-25; orbital 1-3; preorbital 2; preopercular 13-21; lateral mandibular 3-5; mandibular 8-14; lateral supratemporal 1-2; posttemporal 1-2; postotic 2-5; median opercular 1; ventral opercular 1 .

Ventral gill rakers 7-10 (mode 8), dorsal gill rakers 2-3 (mode 2). Anterior cartilaginous basihyal approximately $1 / 3$ of total length; 1-3 (mode 3 ) teeth on second pharyngobranchial. Unicuspid rakers on ceratobranchials. Urohyal deep. Ventral process of anguloarticular reduced. Dermosphenotic absent.

Color in life (Fig. 1b): Males bluish gray body, darker on dorsal half; abdominal region light pale blue; dorsal portion of head bluish gray with some green hues laterally; isthmus and opercular region bright light blue. Dorsal-fin base bluish gray, distal portion ochre; anal-fin base bluish gray, distal 2/ 3 portion bright light blue; caudal fin same tonalities as body, 
bluish in ventral half; pectoral fin base light blue, distal half gray; pelvic fin bright light blue. Suborbital band dark gray, supraorbital dark gray but less conspicuous. Female's body brownish with scattered and sometimes faint dark gray or dark brown vertically elongate spots; abdominal region lighter and yellowish. Fins hyaline. Supra and suborbital band light gray inconspicuous. Faint dark gray vertical bands from origin of dorsal fin to caudal peduncle in $5 \%$ of males collected (all from same population) (Fig. 1c).

Color in alcohol (Fig. 1a, d): Males with brown body, darker in anterior third. Head dark brown, preopercular region lighter. Dark brown supra and suborbital band. Supraorbital band reaching supraorbital neuromast series. Dorsal and anal fins dark brown with basal margin light brown. Caudal, pectoral, and pelvic fins dark brown.

Females light brown body background with scattered darker rounded or slightly elongate spots on whole body. Fins hyaline.

Distribution. The new species lives in temporary ponds from the middle to the upper and eastern río Negro tributaries (río Uruguay basin), and río Yaguarón (Laguna Merín basin) (Figs. 4-5).

Etymology. We name this species to honor Horacio Quiroga, an Uruguayan writer from the early $20^{\text {th }}$ century, whose tales and fables based on his life in the Misiones rainforest inspired the authors to explore nature and its mysteries. Specific epithet is used as a patronym.

\section{Discussion}

The new species described presents all the synapomorphies of the genus Austrolebias (sensu Costa, 2006): deep urohyal, reduced ventral process of the anguloarticular, absence of scales between the corner of the mouth and anterior portion of the preopercular region and ventral portion of the opercular region, dorsal and anal fins in males rounded, presence of a dark gray supraorbital spot, males with long urogenital papilla. The uniformly pigmented body without vertical dark bands or dotted lines is unique for the genus.

The presence of dark vertical bands in the posterior $2 / 3$ of body in $5 \%$ of males of one population offers a possible cue about relationship with other species, because this pigmentation pattern was considered diagnostic for Austrolebias luteoflammulatus (Vaz-Ferreira et al., 1964; Costa, 2006). Other shared characteristics with that species are the elongate body, the conspicuous contact organs on the scales and fin rays (pectoral and anal-fin contact organs supported by bony projections of the fin rays), the presence of one neuromast in the parietal series, and reduced mean number of anal fin rays. However, these features are shared in different combination with other species of the genus. An elongate body is also present in some species of the $A$. elongatus and the $A$. robustus species groups (sensu Costa, 2006). Conspicuous contact organs are also present in these species groups and A. gymnoventris (although this species present reduced bony support in contact organs of fin rays). Number of parietal neuromasts are also reduced in the $A$.
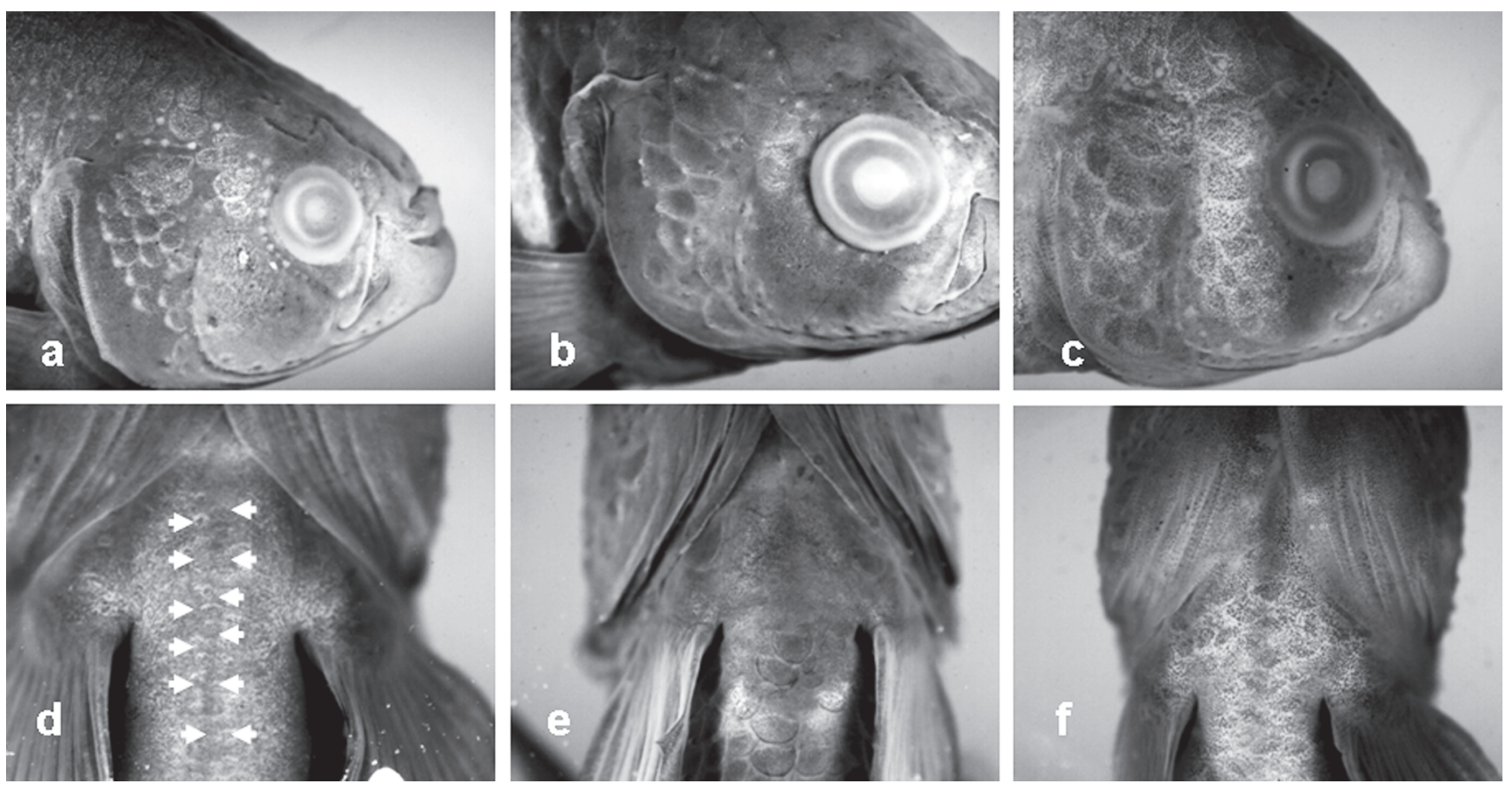

Fig. 3. Squamation pattern in head and abdomen of males. a and d, Austrolebias quirogai (ZVC-P 8725, $38.2 \mathrm{~mm} \mathrm{SL}$ ); b and e, $A$. gymnoventris (ZVC-P 8708, $33.4 \mathrm{~mm} \mathrm{SL}$ ); $\mathbf{c}$ and $\mathbf{f}$, A. luteoflammulatus (ZVC-P 4105, $39.4 \mathrm{~mm} \mathrm{SL}$ ). Arrows indicate scales rows. 
Table 1. Morphometric data of Austrolebias quirogai; *expressed as percentage of standard length, ${ }^{* *}$ expressed as percentage of head length; $\mathrm{H}=$ holotype; $\mathrm{SD}=$ standard deviation.

\begin{tabular}{|c|c|c|c|c|c|c|c|c|c|c|c|}
\hline & \multirow[t]{2}{*}{$\mathrm{H}$} & \multicolumn{5}{|c|}{ Males } & \multicolumn{5}{|c|}{ Females } \\
\hline & & $\mathrm{n}$ & Mean & Min. & Max. & SD & $\mathrm{n}$ & Mean & Min. & Max. & SD \\
\hline Standard length & 36.8 & 91 & 44.0 & 37.2 & 53.7 & 2.5 & 111 & 26.2 & 16.0 & 36.5 & 4.65 \\
\hline Predorsal length* & 41.9 & 91 & 44.0 & 37.2 & 53.7 & 2.5 & 111 & 58.3 & 51.8 & 64.4 & 2.78 \\
\hline Dorsal fin base length* & 51.7 & 91 & 49.7 & 42.6 & 55.3 & 3.0 & 111 & 33.5 & 28.1 & 39.6 & 2.54 \\
\hline Preanal length* & 49.2 & 91 & 51.8 & 45.8 & 61.6 & 2.8 & 111 & 64.1 & 54.2 & 71.5 & 3.21 \\
\hline Anal fin base length* & 42.6 & 91 & 41.7 & 33.6 & 47.1 & 2.4 & 111 & 22.7 & 14.4 & 31.7 & 2.10 \\
\hline Prepelvic length* & 38.2 & 91 & 45.4 & 38.2 & 53.3 & 2.5 & 111 & 54.3 & 33.9 & 63.0 & 3.74 \\
\hline Body depth* & 29.8 & 91 & 29.0 & 23.6 & 33.8 & 1.9 & 111 & 29.7 & 19.7 & 36.8 & 2.80 \\
\hline Peduncle depth* & 14.1 & 91 & 13.2 & 10.2 & 17.5 & 1.2 & 111 & 12.1 & 8.3 & 15.2 & 1.36 \\
\hline Peduncle length* & 11.6 & 91 & 12.7 & 7.6 & 16.2 & 1.7 & 111 & 17.7 & 12.3 & 23.2 & 2.26 \\
\hline Head length* & 22.6 & 91 & 24.6 & 20.2 & 30.3 & 1.9 & 111 & 26.8 & 21.9 & 32.7 & 2.06 \\
\hline Head width** & 79.5 & 91 & 70.6 & 55.1 & 89.7 & 7.7 & 111 & 69.6 & 51.7 & 86.2 & 6.78 \\
\hline Head depth** & 106.6 & 91 & 104.2 & 87.5 & 126.9 & 8.3 & 111 & 93.0 & 74.1 & 113.1 & 7.98 \\
\hline Orbital diameter** & 28.6 & 91 & 29.8 & 19.7 & 37.4 & 3.5 & 111 & 30.7 & 20.0 & 41.5 & 4.06 \\
\hline Interorbital distance $e^{* *}$ & 37.6 & 91 & 38.5 & 29.1 & 50.4 & 4.0 & 111 & 34.3 & 18.3 & 43.6 & 4.46 \\
\hline Snout length** & 30.5 & 91 & 26.3 & 13.0 & 39.3 & 5.7 & 111 & 23.7 & 12.9 & 36.8 & 5.26 \\
\hline Pectoral fin length* & 28.7 & 91 & 26.3 & 19.4 & 31.2 & 2.6 & 111 & 25.3 & 12.5 & 33.4 & 2.77 \\
\hline Pelvic fin length* & 10.5 & 91 & 9.3 & 6.2 & 13.3 & 1.4 & 111 & 10.3 & 6.1 & 15.0 & 1.65 \\
\hline Caudal fin length* & 21.9 & 91 & 26.1 & 16.7 & 32.2 & 3.2 & 111 & 28.6 & 17.6 & 37.9 & 3.25 \\
\hline
\end{tabular}

alexandri species group (sensu Costa, 2006), and A. gymnoventris. Reduced number in anal-fin rays is also shared with $A$. gymnoventris, although this character needs more study because it is both continuous and variable leading to difficulties in delimitation and validation (Loureiro, 2004).

The partial reduction in the scale pattern in preopercular, opercular and abdominal regions is also shared with Austrolebias gymnoventris. However, the patterns of reduction are not the same; whereas $A$. gymnoventris has a completely naked anterior abdomen (Fig. 3e), the new species presents variation in this character: scales completely absent from the anterior abdomen, or one or two rows of scales along its most ventral portion. The preopercle in A. gymnoventris is completely naked (Fig. 3b) whereas in A. quirogai the reduction in squamation is variable, from completely naked to presence of scales in the medial portion. Another species with scale reduction is $A$. cheradophilus (Vaz-Ferreira, Sierra \& Scaglia) (A. elongatus species group); here, reduction occurs in the dorsal region, thus homology of this character is arguable.

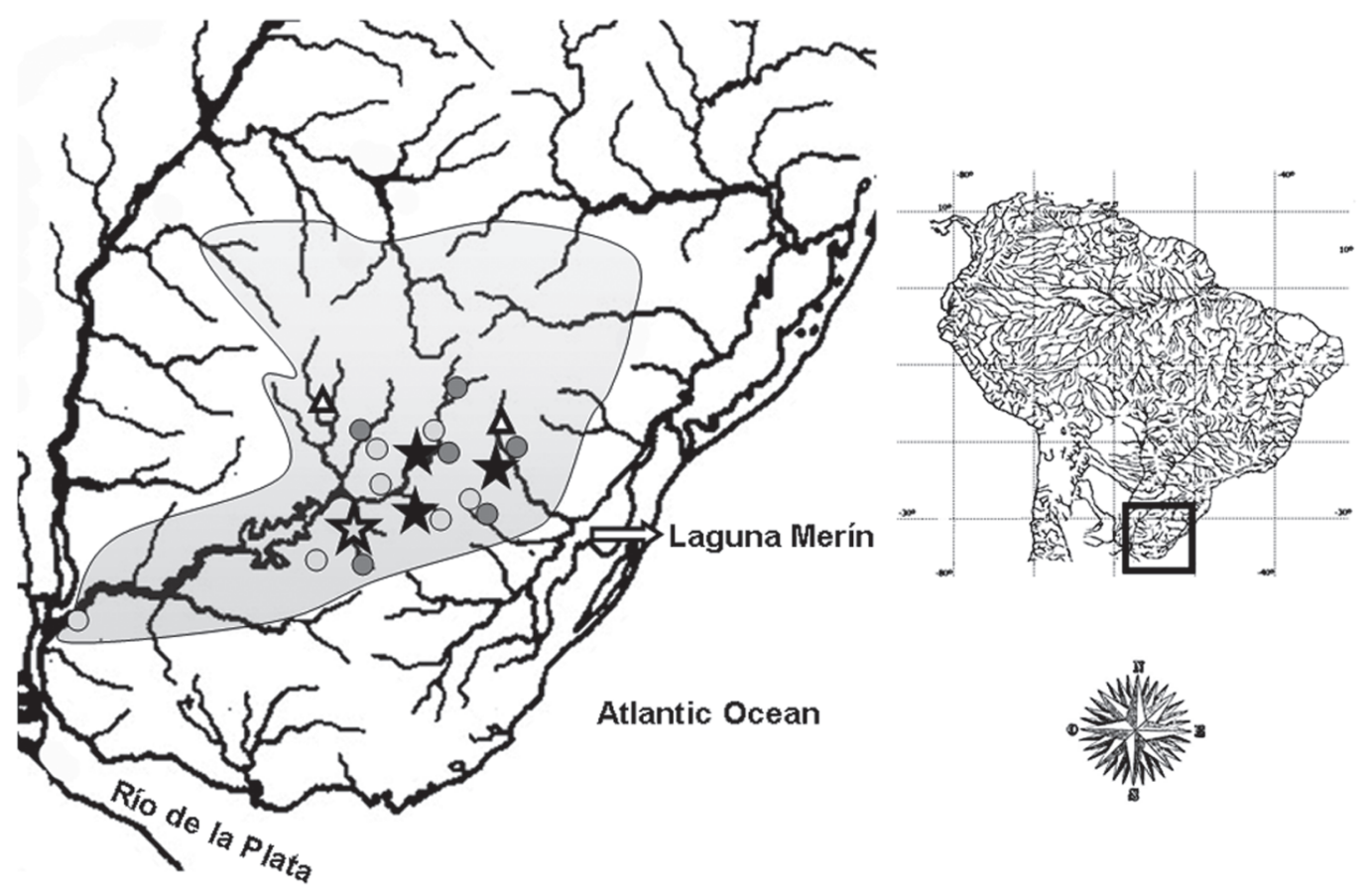

Fig. 4. Distribution of Austrolebias quirogai (stars); empty star indicates type locality. Distribution data of A. arachan (light gray circles), A. vazferreirai (dark gray circles), A. melanoorus (white triangles), and the A. affinis species group (gray shaded area) were obtained from ZVC-P catalogue database, Costa (2006), and Volcan et al. (2010); each point may represent more than one locality. 
The evidence presented here suggests that Austrolebias quirogai may be related to A. gymnoventris and $A$. luteoflammulatus. The first is considered the most basal species of the genus and A. gymnoventris the next most basal (Costa, 2006); previous analyses (molecular and morphological) even considered both to be sister species (García et al., 2000; Costa, 2002; Loureiro, 2004). Thus, $A$. quirogai may have originated early in the phylogenetic history of Austrolebias. Distribution of the new species also points to an ancient origin. The whole area where A. quirogai is distributed occurs over Gondwanic sedimentary materials deposited between the Permian and the Triasic (Chebataroff, 1969). Furthermore, Costa (2010) considered the río Negro basin (lower río Uruguay right tributary) the most ancient endemic area for Austrolebias.

Austrolebias quirogai is present both in río Negro and in one tributary of the Atlantic coastal lagoon Laguna Merín, in plains $100 \mathrm{~m}$ above sea level. This distribution pattern is, in different grades, similar to other three species of Austrolebias: A. arachan, A. melanoorus, and A. vazferreirai (Loureiro et al., 2004) (Fig. 4). This suggests two possible scenarios: dispersion of eggs or vicariance by events of drainage rearrangement. Dispersion may be facilitated by the drought resistant eggs and local movements of wetland birds, however this mechanism seems to be somehow fanciful and distribution patterns of most species of Austrolebias (closely related species in allopatry, and restricted to basins) contradict any hypothesis of significant dispersal.

On the other hand, drainage rearrangement has been extensively proposed as a general geomorphologic mechanism of translocation of freshwater fish in other regions of the world (Bishop, 1995; Waters et al., 2001; Burridge et al., 2006; Craw et al., 2007). Furthermore, Ribeiro (2006) proposed that drainage rearrangement would be the general geomorphological process of transport of fishes from rivers of the Brazilian shield to the Atlantic coastal drainage areas of South America (Ribeiro, 2006). This is supported by distribution patterns and phylogenetic relationships of several Neotropical fish clades. Ribeiro (2006), identified three different patterns that would reflect translocations at different times in the evolution of the continent: an ancient pattern, represented for example by the catfish families Trichomycteridae and Doradidae, where the most basal clades in both groups are endemic to the Atlantic rivers, while the remaining members are well diversified in the shield rivers; an intermediate pattern, observed at the generic level and with sister clades distributed in both areas (e.g., Corydoradinae); a recent pattern evidenced by the common presence of the same species both in the shield rivers and in the coastal rivers. In río Uruguay and the Patos-Merín system some examples include two species of Cnesterodon Jenyns (Lucinda, 2005), Brachyhypopomus

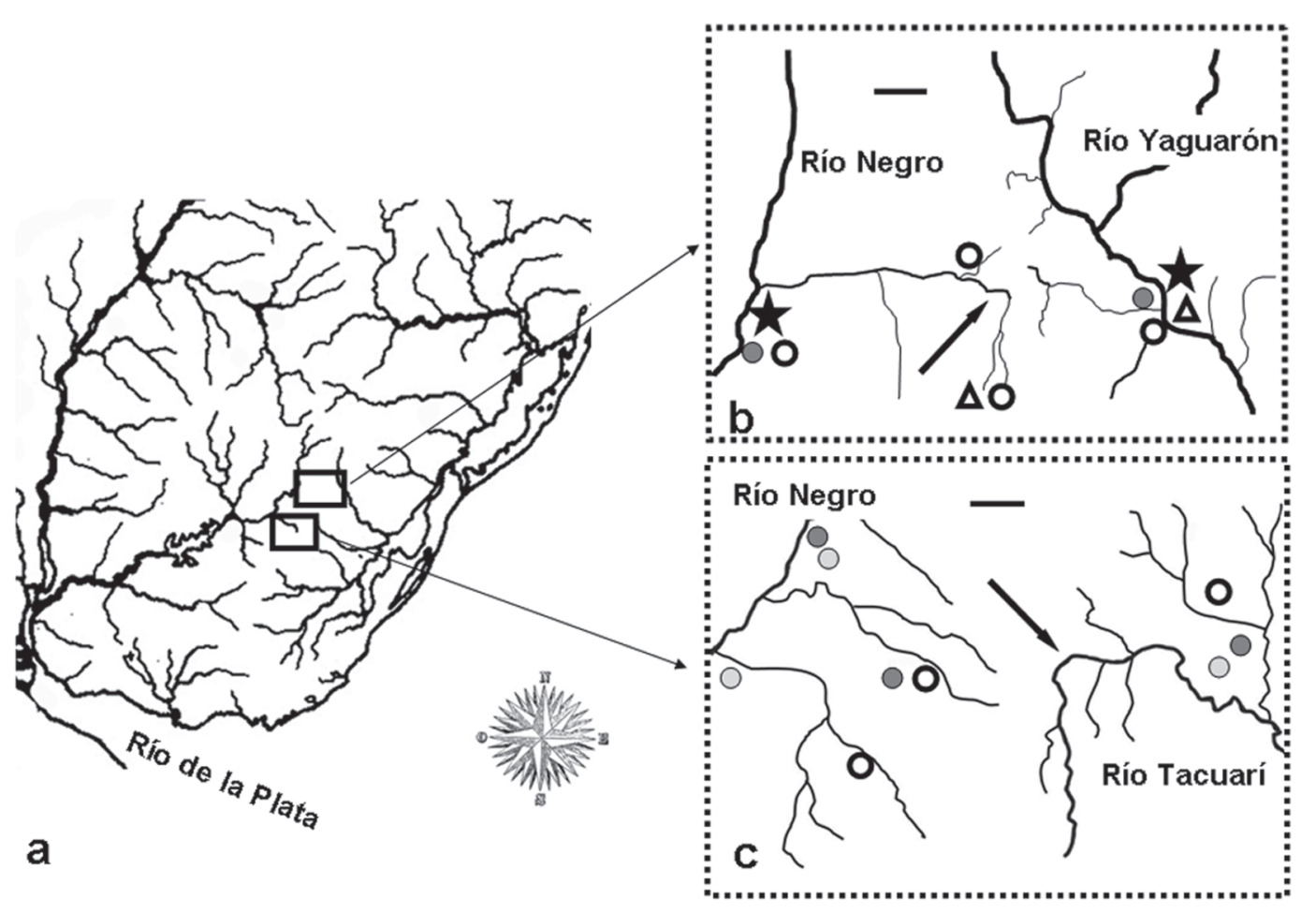

Fig. 5. a. Map of hypothesized areas of drainage rearrangements (empty squares) between río Negro and Laguna Merín tributaries, based on distribution patterns of Austrolebias and rivers morphology (elbows of capture); b. Detailed map of localities of Austrolebias and rivers configurations in río Negro and río Yaguarón; c. Detailed map of localities of Austrolebias and rivers configurations in río Negro and río Tacuarí. Scale bars $=10 \mathrm{~km}$; Black arrows indicate proposed elbow of capture. Austrolebias quirogai (stars), A. arachan (light gray circles), A. vazferreirai (dark gray circles), A. melanoorus (white triangles), and A. affinis species group (white circles). 
bombilla Loureiro \& Silva (Loureiro \& Silva, 2006), and some species of Hypostomus Lacépède (Reis et al., 1990; MontoyaBurgos, 2003); for more examples see Ribeiro (2006).

Distribution of the Austrolebias species reported here are among the most interesting to us. Their shared presence in both the upland shield and Atlantic drainages is a good example of the recent pattern of translocation according to Ribeiro (2006) criteria. The fact that they are all restricted to a small upstream area of two adjacent tributaries (Tacuarí and Yaguarón Rivers) of the Atlantic coastal lagoon Laguna Merín could indicate that drainage rearrangement occurred even more recently than in other regions (Fig. 5). In this context, río Tacuarí channel presents a characteristic elbow of capture configuration considered a good morphological evidence of drainage rearrangement (Bishop, 1995). The site is located just $10 \mathrm{~km}$ away from arroyo Fraile Muerto, a tributary of río Negro (Fig. 5), in a highland plain that presents many wetlands and annual ponds where Austrolebias species inhabit. This is in accordance with the proposed trend that Atlantic drainages capture upland shield drainages (Ribeiro, 2006). The presence of $A$. melanoorus, A. quirogai, and $A$. vazferreirai in río Yaguarón basin, suggests another independent event of drainage rearrangement involving a northern section of the upper río Negro, and as can be seen in Fig. 5, a possible elbow of capture is also observed in this region. However, in this case it is present in a tributary of río Negro, just $6 \mathrm{~km}$ away from the río Yaguarón tributary, indicating that the drainage rearrangement could occur in the opposite direction.

On the other hand, phylogenetic relationships of these species with the rest of the genus suggest a more ancient pattern: the herein proposed related species of A. quirogai ( $A$. gymnoventris and $A$. luteoflammulatus) are endemic to the Laguna Merín basin; the $A$. arachan sister clade is the $A$. adloffi species group (sensu Costa, 2006) that occupies most of the Patos-Merín basin; species related to A. melanoorus and $A$. vazferreirai live in the lower río Uruguay and río Paraná basins. Furthermore, distribution of the A. affinis species group in the upland tributaries of río Uruguay and upland tributaries of Patos-Merín system (Figs. 4-5) could be the consequence of several drainage rearrangements that may be not recent.

The question arises, if these patterns were not recently generated, why do these three species not have wider distributions in the lower Patos-Merín system? The low vagility of annual fishes may be the explanation. Local extinctions may also be highly probable in the unstable environments where these fishes live; and other ecological factors that limit species distributions such as competitive exclusion may also be considered.

The historical and ecological generation of areas of endemism is a central part of the study of biogeography, evolution, and ecology (Lomolino et al., 2006). The PatosMerín system presents a high number of endemisms that could be in part a consequence of drainage rearrangements and posterior population differentiation in isolation. Distribution patterns herein discussed indicate a complex succession of events, where multiple and independent events of drainage rearrangement may have carried freshwater fish species from río Negro to Laguna Merín tributaries. The generation of a robust hypothesis of distribution patterns fish communities in this region is dependent on phylogeographic analysis of Austrolebias and other freshwater species. Detailed geomorphological data are in turn essential to corroborate these phenomena, and also to calibrate molecular clocks to date the events proposed for the species involved.

Comparative material. Uruguay. Austrolebias cheradophilus: ZVCP 4282, 2 males (1 c\&s), 45.8 and $54.9 \mathrm{~mm} \mathrm{SL}, 1$ female $47.4 \mathrm{~mm} \mathrm{SL}$, Rocha, Route 9, km 260, secondary Road to Estancia Sánchez. Austrolebias gymnoventris: ZVC-P 4318, 2 males (1 c\&s), 27.3 and $28.3 \mathrm{~mm}$ SL, Rocha, Route 13, ponds close to Arroyo India Muerta, ZVC-P 4319, 7 males (1 c\&s), 23.1-25.4 mm SL, 3 females, (1 c\&s), 22.6-23.6 mm SL, Rocha, route 13 ponds close to arroyo India Muerta; ZVC-P 8616, 1 male, $27.1 \mathrm{~mm}$ SL, Maldonado, Gruta de Salamanca; ZVC-P 8708, 15 males, 22.3-33.4 mm SL, 24 females, 23.1-29.4 mm SL, Lavalleja, route 8 close to río Cebollatí; ZVC- P 8687, 5 males, 28.2-33.6 mm SL, 5 females, 23.1-29.1 mm SL, Lavalleja, road to Aramendia, close to arroyo Sarandí de las Casas. Austrolebias luteoflamulatus: ZVC-P 3942, 9 males (1 c\&s), 29.8-36.3 mm SL, 8 females, 25.6-36.8 mm SL, Rocha, route 19, $300 \mathrm{~m}$ South from arroyo San Luis; ZVC-P 4354, 4 males, 29.1-34.2 mm SL, 7 females, 24.5$30.0 \mathrm{~mm}$ SL, Treinta y Tres, route 18 , entrance to arrozal Treinta y Tres; ZVC-P 4099, 16 males, 18.5-36.6 mm SL, 23 females, 18.8$29.1 \mathrm{~mm}$ SL, Rocha, route 10, $500 \mathrm{~m}$ from Vivero Forestal Cabo Polonio; ZVC-P 4093, 10 males (2 c\&s), 22.4-30.9 mm SL, 19 females (2 c\&s), 18.7-26.9 mm SL, Rocha, route 10, $1 \mathrm{~km}$ North of entrance to road to Valizas; ZVC-P 4101, 14 males, 24.5-33.9 mm SL, 11 females, 22.3-24.7 mm SL, Rocha, route 10, km 225; ZVC-P 4105, 6 males, 23.5-39.4 mm SL, 2 females, 27.7-31.1 mm SL, Rocha, road to Puerto de los Botes, $500 \mathrm{~m}$ from road. Austrolebias vazferreirai: ZVC-P 4298, 4 males (1 c\&s), 46.7-64.2 mm SL, Cerro Largo, road to airport close to arroyo Conventos.

\section{Acknowledgements}

We are thankful to Wilson Serra for his help with the Portuguese abstract and field work; to T. Olivera, S. Clavijo, J. Bessonart, and F. Teixeira de Mello for their help in the field work. We also thank L. Parenti (NMNH) and two anonymous reviewers for the most valuable comments on the manuscript. This article was partially funded by PEDECIBA, CSIC, PDT 71-08. M. L. is supported by Sistema Nacional de Investigadores, Uruguay.

\section{Literature Cited}

Amato, L. H. 1986. Seis especies nuevas del género Cynolebias Steindachner, 1876, de Uruguay y Paraguay (Cyprinodontiformes, Rivulidae). Comunicaciones Zoológicas Del Museo Historia Natural de Montevideo, 11: 1-27.

Bishop, P. 1995. Drainage rearrangement by river capture, beheading and diversion Progress in Physical Geography, 19(4): 449-473.

Burridge, C. P., D. Craw \& J. M. Waters. 2006. River capture, range expansion, and cladogenesis: the genetic signature of freshwater vicariance. Evolution, 60: 1038-1049.

Chebataroff, J. 1969. Relieve y Costas. Montevideo, Editorial Nuestra Tierra, 68p. 
Costa, W. E. J. M. 1989. Redescrição do gênero Cynolebias (Cyprinodontiformes: Rivulidae), com a descrição de uma nova espécie da bacia do Rio Tocantins. Comunicações do Museu Ciência e Tecnologia da PUCRS, Série Zoologia, 2: 181-190.

Costa, W. E. J. M. 1998. Phylogeny and classification of Rivulidae revisited: origin and evolution of annualism and miniaturization in Rivulid fishes (Cyprinodontiformes: Aplocheiloidei). Journal of Comparative Biology, 3: 33-94.

Costa, W. E. J. M. 2001. The Neotropical annual fish genus Cynolebias (Cyprinodontiformes: Rivulidae): phylogenetic relationships, taxonomic revision and biogeography. Ichthyological Exploration of Freshwaters, 12: 333-383.

Costa, W. E. J. M. 2002. Monophyly and phylogenetic relationships of the Neotropical annual fish genera Austrolebias and Megalebias (Cyprinodontiformes: Rivulidae). Copeia, 2002: 916-927.

Costa, W. J. E. M. 2006. The South American annual killifish genus Austrolebias (Teleostei: Cyprinodontiformes: Rivulidae): phylogenetic relationships, descriptive morphology and taxonomic revision. Zootaxa, 1213: 1-162.

Costa, W. J. E. M. 2010. Historical biogeography of cynolebiasine annual killifishes inferred from dispersal - vicariance analysis. Journal of Biogeography, 2010: 1-10.

Craw, D., C. Burridge, L. Anderson \& J. M. Waters. 2007. Late Quaternary river drainage and fish evolution, Southland, New Zealand. Geomorphology, 84: 98-110.

Dingerkus, G. \& L. D. Uhler. 1977. Differential staining of bone and cartilage in cleared and stained fish using alcian blue to stain cartilage and enzymes for clearing flesh. Stain Technologies, 52: 229-232.

Ferrer, J., L. R. Malabarba \& W. J. E. M. Costa. 2008. Austrolebias paucisquama (Cyprinodontiformes: Rivulidae), a new species of annual killifish from southern Brazil. Neotropical Ichthyology, 6: $175-180$.

García, G. 2006. Multiple simultaneous speciation in killifishes of the Cynolebias adloffi species complex (Cyprinodontiformes, Rivulidae) from phylogeography and chromosome data. Journal of Zoological Systematics and Evolutionary Research, 44: 75-87.

García, G., M. Loureiro, N. Berois, M. J. Arezo, G. Casanova, G. Clivio \& A. Olivera. 2009. Pattern of differentiation in the annual killifish genus Austrolebias (Cyprinodontiformes; Rivulidae) from a biosphere reserve site in South America: a multidisciplinary approach. Biological Journal of the Linnean Society, 98: 620-635.

García, G., G. Wlasiuk \& E. Lessa. 2000. High levels of mitochondrial cytochrome $\mathrm{b}$ divergence in annual killifishes of the genus Cynolebias (Cyprinodontiformes, Rivulidae). Zoological Journal of the Linnean Society, 129: 93-110.

Lomolino, V. M., B. R. Riddle \& J. H. Brown. 2006. Biogeography, Third Edition. Sinauer Associates, Inc. Publishers, Massachusetts, $847 \mathrm{p}$.
Loureiro, M. 2004. Sistemática y biogeografía de los peces anuales de la subtribu Cynolebiatina (Cyprinodontiformes: Rivulidae: Cynolebiatinae). Unpublished Ph.D. Dissertation, Montevideo, PEDECIBA-Biología, 119p.

Loureiro, M., M. Azpelicueta \& G. García. 2004. Austrolebias arachan (Cyprinodontiformes, Rivulidae), a new species of annual fish from northeastern Uruguay. Revue suisse de Zoologie, 111:21-30.

Loureiro, M. \& G. García. 2004. Cynolebias reicherti a new annual fish (Rivulidae: Cynolebiatinae) from southern Laguna Merim basin. Acta Zoológica Lilloana, 48:13-25.

Loureiro, M. \& G. García. 2008. Austrolebias reicherti Loureiro \& García, a valid species of annual fish (Cyprinodontiformes: Rivulidae) from southwestern Laguna Merin basin. Zootaxa, 1940: 1-15.

Loureiro, M. \& A. Silva. 2006. A new species of Brachyhypopomus (Gymnotiformes, Hypopomidae) from northeast Uruguay. Copeia, 2006: 667-673.

Loureiro, M., F. Teixeira de Mello, A. D'Anatro \& V. Cardozo. 2007. Austrolebias cinereus. In: IUCN 2010. IUCN Red List of Threatened Species. Version 2010.4.

Lucinda, P. H. F. 2005. Systematics of the genus Cnesterodon Garman, 1895 (Cyprinodontiformes: Poecilidae: Poeciliinae) Neotropical Ichthyology, 3: 259-270.

Montoya-Burgos, J. I. 2003. Historical biogeography of the catfish genus Hypostomus (Siluriformes: Loricariidae), with implications on the diversification of Neotropical ichthyofauna. Molecular Ecology, 12: 1855-1867.

Reis, R. E., C. Weber \& L. R. Malabarba. 1990. Review of the genus Hypostomus Lacépède, 1803 from southern Brazil, with descriptions of three new species (Pisces, Siluriformes, Loricariidae). Revue Suisse de Zoologie, 97: 729-766.

Ribeiro, A. C. 2006. Tectonic history and the biogeography of the freshwater fishes from the coastal drainages of eastern Brazil: an example of faunal evolution associated with a divergent continental margin. Neotropical Ichthyology, 4: 225-246.

Vaz-Ferreira, R., B. Sierra \& S. Scaglia. 1964. Tres especies nuevas del género Cynolebias Steindachner, 1876 (Teleostomi, Cyprinodontidae). Comunicaciones Zoológicas del Museo Historia Natural de Montevideo, 8: 1-35.

Volcan, M. V., L. E. K. Lanés, A. C. Gonçalves \& M. M. Cheffe. 2010. First record of annual killifish Austrolebias melanoorus (Amato, 1986) (Cyprinodontiformes: Rivulidae) from Brazil, with data on habitat and conservation. Journal of Applied Ichthyology, DOI: 10.1111/j.1439-0426.2010.01626.x.

Waters, J. M., D. Craw, J. H. Youngson \& G. P. Wallis. 2001. Genes meet Geology: Fish Phylogeographic pattern reflects ancient rather than modern drainage connections. Evolution, 55: 18441851. 